\title{
The Impact of Active Visualisation of High School Students on the Ability to Memorise Verbal Definitions
}

ANAMARIJA ŠMAJDEK ${ }^{1}$ AND JURIJ SELAN ${ }^{\star 2}$

$\approx$ The era of visual communication influences the cognitive strategies of the individual. Education, too, must adjust to these changes, which raises questions regarding the use of visualisation in teaching. In the present study, we examine the impact of visualisation on the ability of high school students to memorise text. In the theoretical part of the research, we first clarify the concept of visualisation. We define the concept of active visualisation and visualisation as a means of acquiring and conveying knowledge, and we describe the different kinds of visualisation (appearance-based analogies and form-based analogies), specifically defining appearance-based schemata visualisations (where imagery is articulated in a typical culturally trained manner). In the empirical part of the research, we perform an experiment in which we evaluate the effects of visualisation on students' ability to memorise a difficult written definition. According to the theoretical findings, we establish two hypotheses. In the first, we assume that the majority of the visualisations that students form will be appearance-based schemata visualisations. This hypothesis is based on the assumption that, in visualisation, people spontaneously use analogies based on imagery and schemas that are typical of their society. In the second hypothesis, we assume that active visualisation will contribute to the students' ability to memorise text in a statistically significant way. This hypothesis is based on the assumption that the combination of verbal and visual experiences enhances cognitive learning. Both hypotheses were confirmed in the research. As our study only dealt with the impact of the most spontaneous type of appearancebased schemata visualisations, we see further possibilities in researching the influence of visualisations that are more complex formally.

Keywords: visualisation, visual recall, active visualisation, appearancebased visualisation, form-based visualisation, appearance-based schemata, memory

1 High School Josip Jurčič, Ivančna Gorica, Slovenia.

$2{ }^{\star}$ Corresponding Author. Faculty of Education, University of Ljubljana, Slovenia; jurij.selan@pef.uni-lj.si. 


\section{Vpliv aktivne vizualizacije na sposobnost pomnjenja besedne definicije pri dijakih}

ANAmarija Šmajdek IN Jurij Selan

$\approx$ Doba vizualnih komunikacij vpliva na spoznavne strategije posameznika. Temu se mora prilagajati tudi šolstvo, zato se pojavljajo vprašanja, povezana $\mathrm{z}$ uporabo vizualizacije v izobraževanju. V raziskavi smo ugotavljali vpliv vizualizacije na sposobnost pomnjenja besedila. V teoretskem delu najprej opredelimo pojem vizualizacije, definiramo pojem aktivne vizualizacije, analiziramo vizualizacijo kot način pridobivanja in posredovanja znanja ter opredelimo oblike vizualizacij (podobotvorne in oblikotvorne analogije), pri čemer največ pozornosti namenimo podobotvornim šablonam. V empirični raziskavi nato izvedemo eksperiment, $\mathrm{v}$ katerem pri dijakih merimo učinke vizualizacije na sposobnost pomnjenja težko razumljive besedne definicije. Glede na teoretične ugotovitve si zastavimo dve hipotezi. V prvi predvidevamo, da bo večina vizualizacij, ki jih bodo tvorili učenci, podobotvornih šablon. Hipoteza temelji na predvidevanjih, da ljudje v vizualizaciji spontano uporabljamo podobotvorne analogije in kulturno priučene sheme, torej podobotvorne šablone. V drugi hipotezi pa predvidevamo, da bodo aktivne vizualizacije statistično pomembno pripomogle $\mathrm{k}$ pomnjenju besedne definicije. Ta hipoteza temelji na predvidevanjih, da kombinacija čutnih izkustev verbalnega in vizualnega krepi kognitivne sposobnosti pri učenju. Obe hipotezi smo v raziskavi potrdili. Ker smo v preučevali le vpliv najbolj spontanih vizualizacij, to je podobotvornih šablon, se odpirajo nadaljnje možnosti raziskovanja vizualizacij, pri katerih bi bil večji poudarek na kultivaciji likovnega jezika, to je na oblikotvorni kompleksnosti.

Ključne besede: vizualizacija, vizualni priklic, aktivna vizualizacija, podobotvorne analogije, oblikotvorne analogije, podobotvorne šablone, pomnjenje 
"Neither feelings nor concepts, but images are the fundament of human cognition."

(Muhovič, 1998, p. 43)

\section{Introduction: Teaching about, within and with visuality}

The era of visual communication affects the cognitive strategies of the individual. People are able to process visual data up to 60,000 times faster than text data (Burmark, 2002), and visual literacy is gaining in force and influence more than ever (Rutar Ilc, 2013). Nowadays, technology enables anyone to access images and image information, to process images, to recycle images and to produce their own images. Education must adapt to these changes, which raises questions regarding the cultivation of visual literacy and visuality in general.

We distinguish between teaching about visuality, teaching within visuality and teaching through visuality. Teaching about visuality includes learning (knowledge, understanding, analysis and evaluation) the concepts and content of visual perception theories, art theories, art history, fine art technology and other theoretical knowledge related to visuality. Teaching within visuality includes the systematic and continuous acquisition of visual expression knowledge, abilities and skills, and therefore the development of visual thinking, of the imagination and of the handling of artistic materials and tools in different fields of visual art (painting, drawing, photography, design, sculpture, etc.). Finally, teaching through visuality refers to how strategies of visualisation are used as a tool to teach other subjects: music, mathematics, language, history, etc. In this case, visuality becomes a mode to deepen understanding in other subject areas. In teaching through visuality, the methods and strategies of visual art are used to promote cognitive, emotional, experiential and motivational gain in other subject areas (Tomšič Čerkez et al., 2011, p. 221).

Given that, nowadays, the student's active role in education and constructive learning is emphasised, recognising the significance of visuality is even more important. The contemporary teacher is no longer treated just as a source of knowledge, but as a planner and designer of the learning environment, learning situations and learning processes, thus providing students with a suitable environment for personal development (Biesta, 2008). Hence, the modern teacher should be aware of the visuality of our era and should provide students with visualisation strategies.

In the present study, we therefore sought to evaluate the influence of visualisation, which is stimulated by the teacher, on the students' ability to acquire, understand and memorise knowledge. 


\section{Theoretical background}

\section{Active visualisation as a means of acquiring and conveying knowledge}

Visualisation is the process of shaping thoughts into visual images or pictures, which can also include a physical form of encoding messages into material spatial relations.

For the purposes of the study, we distinguish between two modes of visualisation: passive and active. Generally speaking, all visualisation is active; however, there are two reasons why we find it useful to introduce the dualism of active/passive visualisation.

The first reason is cognitive. The spontaneous process of visualisation whereby images appear in thinking without the person him/herself being particularly aware of this should be distinguished from the active approach whereby the thinker actively involves him/herself in the process of visualisation, thus requiring his/her reflective engagement. Therefore, passive visualisation remains only at the level of spontaneous imagination, while active visualisation requires the visual articulation of the imagined in some material form and physical spatial relations (such as a drawing, a plan, a spatial model, etc.). Poet Paul Valéry described this critical role of active visualisation for cognition a century ago: "There is a big difference between observing an object without a pencil in the hand and seeing it whilst drawing. / ... / Even the most well-known object becomes completely different when we try to draw it: we notice that we don't really know it, that we never really had seen it before" (Valéry, 1955, p. 40). Although in this quote Valéry specifically refers to the creative features of the artistic processes that take place while drawing (or painting, sculpting, etc.), this creative activity of visualisation carries a broader cognitive relevance for science and education. Anyone who wants to acquire and invent new knowledge will benefit significantly from "a pencil in the hand". Hence, scientists have always used the different dimensions of visual cognition in the process of inventing new knowledge (Trumbo, 1999, p. 419).

Frelih (2014) discovered that visualisation has a striking cognitive importance for persons with visual deficits, as well. He analysed examples of drawings made by blind persons after tactile observation of an object. The blind persons touched an unknown object (a model of an airplane) and drew (embossed) their concepts of it into a flat wet clay surface. Plaster casts of these drawings were then made to display a tactile relief. Analysing these "drawings", Frelih observes: "The drawing is not only an aesthetic object. Through its use, 
we explain to ourselves what and how we see; therefore, it has cognitive potential. The participant received a model of an airplane and identified it as a fish by palpation. We did not disclose to her that she was deluded; we waited for her to draw it in clay and then palpated the cast relief of her embossed drawing. After palpating the cast relief of her clay drawing, the participant suddenly realised that the object she had drawn was not a fish, but an airplane. The drawing that the blind participant had made therefore informed her about the specific differences between the two otherwise structurally similar shapes: an airplane and a fish" (Frelih, 2014, p. 104). Based on these findings, Frelih concludes: "What a person has not yet understood, has not yet discovered and invented, is equally invisible to the blind as to the seeing" (Frelih, 2014, p. 100).

The second reason for differentiating between active and passive visualisation is educational. We distinguish between visualisations that are prepared by a teacher in advance and only communicated to a student in the learning process (and are therefore not an outcome of the student's own creative visual thinking), and visualisations that are constructed by the student him/herself with the intention of learning while articulating them. Whereas the artist is involved in active visualisation with the intention of expressing him/herself, and the scientist with the intention of discovering new scientific knowledge, the student engages in active visualisation in order to learn more successfully and to understand and memorise more deeply what $s /$ he has learned. Since, in contemporary teaching doctrine, knowledge should not only be communicated by the teacher, but should be constructed by the student him/herself, visualisations premade by the teacher should also be replaced by the students' own active visualisations of the learning content: students should make their own drawings, images, models, schemas, diagrams, etc. In the learning process, the student's active engagement in visualisation is linked to his/her individual ability to construct knowledge, and therefore plays a key role in achieving higher levels in learning (e.g., of complex abstract concepts) (Twissel 2014, p. 188). In a similar sense, a passive visualisation, pre-constructed by the teacher, could also activate the student, if s/he reflectively reconstructs it by redrawing or reconstructing it. In the process of translating meaning from one modality to another (from visual to written form or vice versa), "transmediation" occurs in which the knowledge is rearticulated, with this reinterpretation consequently intensifying the conceptual links in knowledge production (Sort, Harst, Burke, 1996), or, as Muhovič puts it: “Through visualisation, a person is actively and constantly involved in the process of the (re)construction and (re)creation of information, or in the process of translating information that had been communicated to him/her in one modality into alternative modalities, thus expanding the scope of man's ability to operate with experience" (Muhovič, 1998, p. 44). 
The concept of active visualisation is also closely related to the concept of visual communication and visual literacy. Mendelson (2004) defines visual literacy as an actively acquired ability that enables us to understand and interpret visuality. Complex achievements of visual literacy include visual learning, visual thinking and visual communication (Trumbo, 1999). Visual communication is the process of sending and receiving messages using visual images and representations in order to structure the message (Trumbo, 1999), while visual thinking is the ability of the mind to combine observation and understanding from every area of cognition (learning) (Arnheim, 1969).

\section{Visualisation strategies between appearance-based and form-based analogies}

Muhovič (1998) distinguishes between two types of basic visualisation strategies: appearance-based analogies and form-based analogies. Appearancebased analogies connect two phenomena based on the similarity/resemblance of their (superficial) appearance or content; examples are depiction and simulation of appearance, appearance reconstructions (explicit images, imaginative reconstructions of concepts, appearance-based schemata) and visual metaphors. Form-based analogies, on the other hand, bond two phenomena based on their structural equivalence and the spatial relationships of their formal structure; examples include visual metonymies, structural reconstructions, spatial formal models, schematic representations, mind maps, etc. According to Muhovič, form-based analogies are of a higher taxonomic level and are therefore an upgrade of appearance-based analogies.

Within the dualism of appearance-based and form-based visualisations, we further divide visualisations based on the level of their standardisation or schematisation. The presence of standardisation in visualisation partly coincides with the dualism of appearance-based and form-based visualisations: when there is little form-based thinking in progress, visualisation mostly relies on imitational or representational clichés. We therefore call such visualisations appearance-based schemata visualisations. These are not inventive visual expressions or inventive visual representations based on attentive observation, but visualisations in which imagery is articulated in a typical culturally trained manner, so little formal invention is present. They are mostly established when people, in their childhood, pick up certain generic (drawing) templates that originate in their society and culture; examples of such appearance-based schemata are spruces made of triangles, houses made of a triangle and a square with rectangles for windows and doors, windows divided by crosses, two arches for 
flying birds, clouds made of semicircles, cloudlike trees, the sun represented in the upper corner of the drawing sheet by a line and rays, the sun made of a circle and rays, facial expressions as a smiley, stickmen, etc. In these drawings, stickmen are often accompanied by simple template attributes. Children and adults alike spontaneously use such stereotyped drawings, especially when they are trying to avoid too much effort and are aiming for rapid and economical solutions in visualisation. It is typical of the human mind to spontaneously aspire to such standard thinking patterns for reasons of economy (De Bono, 1989).

Despite such imagery schemata lacking inventiveness and formal ingenuity, they nevertheless represent the most basic, common, standard and widespread way of visualisation. We therefore wanted to test their educational potential in our empirical research.

\section{The role of visualisation in education}

In educational psychology, it is considered that learning is made easier and more efficient when information is perceived by multiple senses, which is particularly true for the simultaneous use of vision and hearing. Visuality plays the central role within human multimodal communication competence development (Britisch, 2009). It is the most important way of storing experience and is a springboard for creative thinking (Panić, 2005). Visual images also play a central role in literacy development. Pictures are a tool for learning the letters. A picture - for example, when a child browses through a picture book in his/her parent's lap - becomes a "conversation piece" that serves as a strategy for literacy development. Furthermore, seeing and sensing his/her own fingers is a child's first model for counting and calculating. With the aid of visual materials, the ability to observe is developed amongst students, the acquisition of new information is facilitated, acquired knowledge is made more permanent, etc. There is no subject in school that could not convey its knowledge through visual materials (Furlan \& Kobola, 1970, p. 5).

Visualisation can be used in all stages of the learning process: as an introduction of the topic or to provide motivation; at the core of the lesson, to articulate concepts and illuminate content; and, at the end, to summarise, repeat and reinforce the knowledge and its application. Each subject area has its own characteristics that can benefit from the use of visualisations. Images are an indispensable tool in natural science education, either in the transfer of concepts or as instructions in an experiment, clarifying the procedures. In physics, images can be used for demonstration of the logic of equations for the density of materials, for anticipating the outcome of experiments, for simulating and 
monitoring certain states, etc. (Udir, 2013). There are abundant visualisation possibilities for science education, which offer a variety of models embracing complex analogies and metaphors of real science objects. Thus, visual models are a simplified representation of reality and serve as a tool for interpretation and explanation, making it easier for students to understand and remember information (Vogrinc \& Devetak, 2007, p. 198).

Abundant visualisation has not always been available, so one must also be aware of the negative aspects and pitfalls of visualisation in education. Whereas, in the past, visuality was largely excluded from education (Furlan \& Kobola, 1970), teachers nowadays must be aware that students can be overloaded with images; they should therefore pay attention to carefully selecting images and helping students to extract what is essential from this plurality of images. Our time is marked by the intrusive inundation of images (Prevodnik, 2013); not all visual material is good, simply because it is visual. Therefore, the teacher must help students to process visual information out of the multitude of visual data. If visual content fails to display the subject in a clear and understandable way, it is incomprehensible and therefore harmful (Panić, 2005, p. 246). The ability to think critically about the images that surround us is one of the key skills today (Tomšič Čerkez, 2013, pp. 30-31). We should also be aware that visual materials can be highly comprehensible to people with previous experience and proper visual knowledge, but incomprehensible to people without the proper visual knowledge. Therefore, every visualisation in the learning process requires triangular verification: from the standpoint of the subject matter, the standpoint of its formal articulation or design, and the standpoint of the student's visual knowledge and abilities (Panić, 2005, p. 246).

\section{Empirical research}

\section{Research problem, objectives and hypotheses}

Mental visual representations have an impact on cognitive processes in the brain: on the control of movement, attention, perception, planning and memory. Therefore, through visualisations, the brain actually trains for a real action (LeVan, 2009). In order to enhance rapid reading, for instance, the brain uses images of words already known and forms new images of newly learned words. It is possible to locate a specific centre in the brain (VWFA, visual word form area) that is responsible for the visualisation of words (Jiang \& Riesenhuber, 2015). This means that visual learning style is not a prerequisite for learning by visualisation, but all students can learn by visualisation equally (Mendelson, 2004). 
Our brains closely support the memorisation of words in a visual way. Therefore, in the empirical research, we wanted to investigate the impact of active visualisation on the cognitive ability of students to memorise (difficult to understand) verbal definitions, ${ }^{3}$ especially the effect of active visualisation on the long-term semantic memory (Tulving, 1972). ${ }^{4}$ In addition, we were interested in the types of active visualisations that students spontaneously form for this purpose. We therefore established two hypotheses:

- Hypothesis 1: The majority of active visualisations that the students in the experimental group form will be appearance-based schemata visualisations. Hypothesis 1 is based on theoretical presuppositions that, in visualisation, people spontaneously use standardised appearance-based analogies, i.e., appearance-based schemata visualisations.

- Hypothesis 2: Active visualisation will have a statistically significant impact on the students' ability to memorise a verbal definition. Hypothesis 2 is based on theoretical expectations that the combination of verbal and visual perceptual experience strengthens cognitive skills in learning, which subsequently implies that visualisations that are added to verbal learning techniques significantly contribute to memorisation.

\section{The sample and the timeframe of the research}

In the experiment, four classes (two classes in two high schools) of firstyear students were included (a total of 96 students aged 15-16 years). In each of the two schools, one of the two classes represented the experimental group and the other class the control group. The experimental group included 51 students and the control group 45 students. Comparability of the groups was tested with regard to achievements in art history tests. There were no significant differences between the groups (Mann-Whitney U Test $\mathrm{p}=0.35$ ).

The experiment was conducted from January 2015 to May 2015.

3 This idea is based on earlier research (see Šmajdek, 2013) in which we investigated how high school students break down verbal definition by visualisation.

4 Since the person does not remember only the content of visualisation, but also the process of visualisation as an "event", and can therefore relive it in the memory, visualisation also has an impact on episodic memory. By impacting episodic memory, visualisation subsequently has an impact on semantic memory, since recalling the process of visualisation helps the individual to recall the content of what $\mathrm{s} /$ he has been memorising through visualisation. 


\section{Methodology and conducting of the research}

The experiment was conducted at art class lessons. The students in both the control group and the experimental group were first presented with the same verbal definition, which we wanted them to understand and memorise. The following definition by Milan Butina, which defines the nature of a work of art, was presented to the students: "A work of art is a way of material existence of an artist's spiritual responses to the situation in nature and society." (Original in Slovene: "Likovna umetnina je način materialnega bivanja duhovnih odzivov umetnika na stanje v naravi in družbi.") (Butina, 1995, p. 347).

The definition was projected on a screen and the students were set the task of explaining and remembering the definition in two different ways, as described below.

In the control group, the students were, in the first step, asked to understand and remember the definition simply by reading it (reading repetition). In the second step, the projection was turned off and the students were assigned to pairs in which each student presented what s/he had understood and memorised to his/her classmate. In the third step, the students were asked to write down the definition by memory. Finally, in the fourth step, the students made a transcript of the definition from the projection and compared it to the definition written out by memory.

In the experimental group, the key difference in the process was that, besides understanding and memorising by reading repetition, visualisation was added, in the form of drawings. Thus, in the first step, in addition to reading the definition, the students were asked to understand and remember it with the aid of active visualisation, by drawing it. The students had five minutes for visualisation. In the second step, each student shared his/her drawing with a classmate in a pair and told him/her what s/he had understood and memorised. The third and the fourth steps were the same as in the control group. The students were asked to write down the definition by memory, after which they wrote a transcript from the projection and compared it with the definition written by memory.

Three weeks after the lessons, all of the students were tested. The test consisted of three tasks: "draw the definition" (the students had to visualise Butina's definition by memory by drawing it; the students in the control group therefore drew the definition for the first time, whereas the students in the experimental group drew it for the second time); "write the definition" (the students had to write down Butina's definition by memory); and "pick the correct statement" (the students had to circle two correct statements that paraphrased Butina's definition out of six offered). 
In order to investigate Hypotheses 1 and 2, qualitative and quantitative methods were used.

Hypothesis 1 - the use of appearance-based schemata - was investigated by the formal visual analysis of the student's lesson drawings in the experimental group. Hypothesis 2 - the impact of visualisation on the ability to memorise and understand a verbal definition - was investigated using the results of the test. The results of the test were analysed qualitatively (using formal visual analysis and codification) and quantitatively (using statistics).

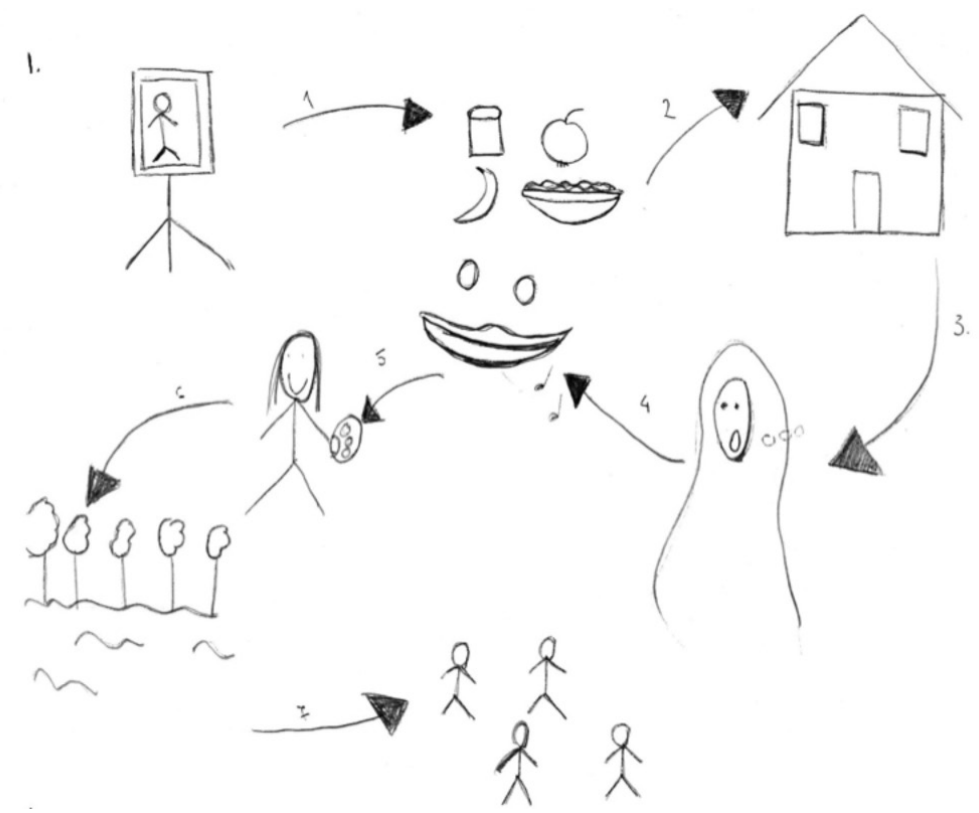

Figure 1

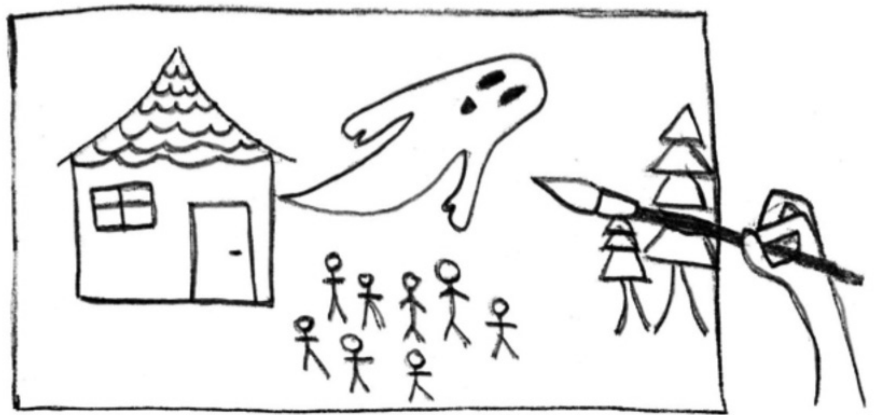

Figure 2 


\section{Research results and interpretation}

\section{Verification of Hypothesis 1}

In order to verify Hypothesis 1, a formal visual analysis of the students' drawings in the experimental group (e.g., Figures 1 and 2) was used to determine the level of appearance-based and form-based visualisations. It was discovered that, in the vast majority of the drawings, the content of the words and phrases is converted into visual form through the use of those metaphorical images (i.e., visual metaphors) that are, predictably, superficially closest to the content expressed by the words, e.g., spirituality à a ghost; an artist à a man with certain attributes or one single attribute (a brush, a palette, etc.); existence à a house; society à a group of people; nature à trees, etc. These visual metaphors are also articulated in a distinctly schematised and standardised mode of appearance (a cliché ghost, a stickman, a box-like house with a triangle roof, trees made of triangles, etc.). We therefore established that, in most of the drawings, appearance-based schemata visualisations dominated.

In our opinion, the reason why the students used appearance-based schemata visualisations is as follows. The students did not receive any instructions to pay attention to the complexity and formal structure of their drawings, nor were they alerted to be attentive to artistic originality in their visualisations. Furthermore, they only had five minutes available for visualisation, so their visualisations had to be produced efficiently and quickly. The students therefore spontaneously resorted to the type of visualisation that enables a semantic message expressed by words to be more easily and quickly transferred into pictures. Consequently, they translated the content of the text into appearance-based analogies based on physical appearance. Due to the time limitation, and because the instructions only suggested the semantic aspect of visualisation, not the aesthetic and creative aspect, the students made appearance-based analogies requiring the least effort possible, leading them to use culturally trained clichés resulting in appearance-based schemata drawings. It can also be observed that many of the students' drawings are relatively small, positioned on the upper left-hand corner of the A4 paper, and drawn as a linear sequence from left to right. In this sense, the visualisations mimic the logic of a text, which, together with their appearance-based and schematic nature, gives them a kind of hieroglyphic character.

Based on the formal visual analyses of the students' visualisations, we concluded that our presuppositions in Hypothesis 1 - that, in visualisation, students spontaneously use appearance-based schemata visualisations - are confirmed. 


\section{Verification of Hypothesis 2}

In order to investigate Hypothesis 2, we qualitatively (using formal visual analysis and codification) and quantitatively (statistically) analysed the results of the tasks in the test.

\section{Task 1: "Draw the definition"}

In the first task, we were interested in three things. First, we observed the visual memory (the visual recall) of the students in the experimental group, i.e., the extent to which the visualisations in the test matched the visualisations previously made during the lesson in class. Second, we wanted to give the students of the control group, who had not made visualisations during the lesson in class, an opportunity to make visualisations. We could subsequently observe how their visualisations differed from those of the students in the experimental group. Third, we were interested in the correlations between the control group and the experimental group in relation to the first task ("draw the definition") and the second task ("write the definition"). We were especially interested in whether any students in the control group would successfully visualise the definition (the first task), but would nonetheless have difficulties writing it down properly (the second task).

In the control group, 30 students (out of 45) solved the first task, meaning that 15 students in this group left the task unsolved. A formal visual analysis of the drawings made by the students in the control group revealed the following interesting findings. Most of the drawings are appearance-based schemata visualisations, and therefore analogous to the drawings of the experimental group. The most interesting finding, however, is that a small but significant number of drawings (11 out of 30 ) visualise the text itself and not the content of the text. These students obviously (mis)understood the instructions as requiring them to draw a picture of the text itself; for instance: a large or a small blank frame (Figure 3); wavy or straight lines that simulate text (Figure 4); the actual writing (word by word) of the definition (which means that the student obviously understood an inscription of a word as a picture of it) (Figure 5); pictures of notebooks or books with lines, while we simultaneously see the student's head drawn from behind and the brain inside (Figure 6).

Obviously, this suggests that many of the students in the control group memorised the picture of the text itself (e.g., how the text was projected on the screen), which is probably a consequence of the fact that, in the control group, the focus during the lesson was placed solely on verbal learning, hence the visual recall also adhered to the "image of the text". 

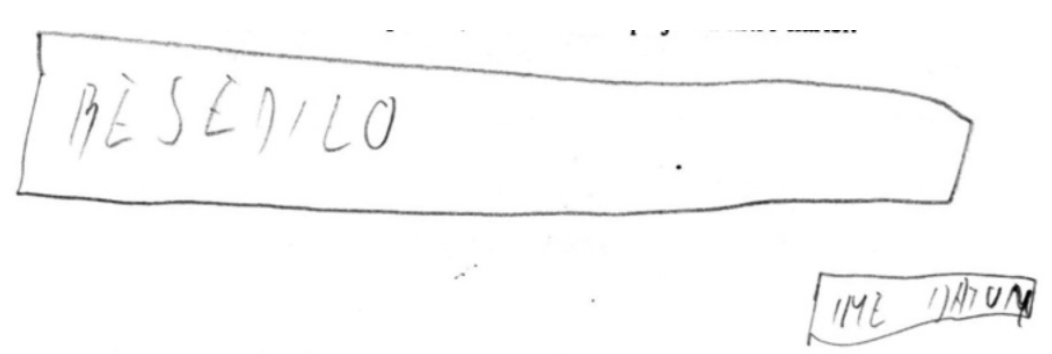

Figure 3

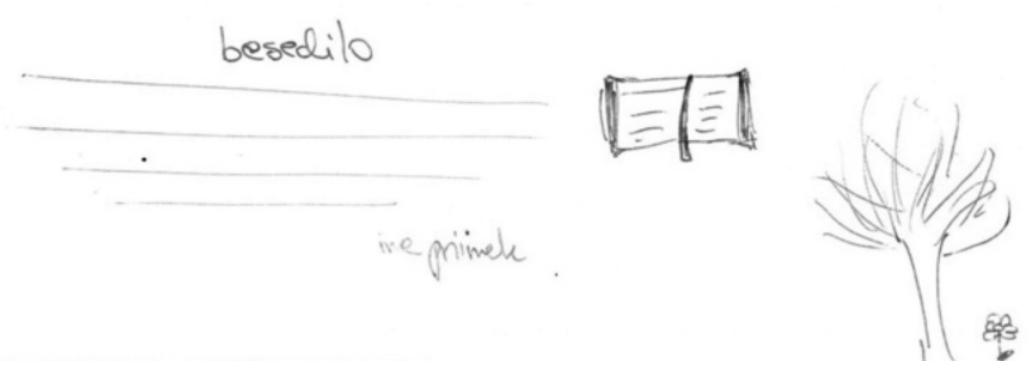

Figure 4

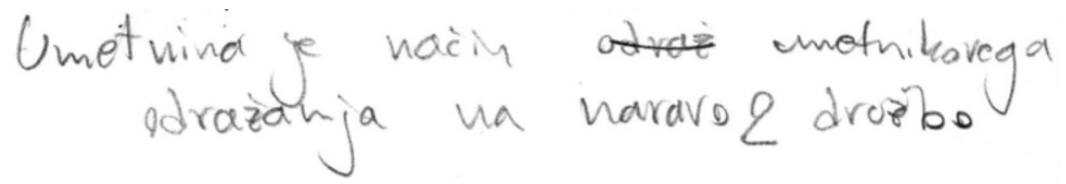

Figure 5
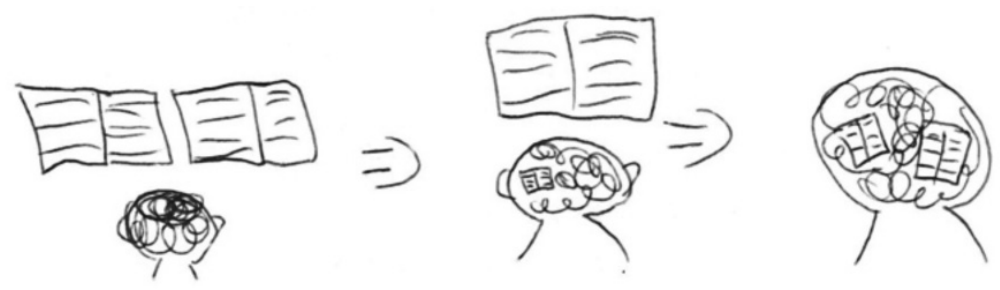

Figure 6

The test drawings of the students in the experimental group were compared using formal visual analysis to the drawings that the same students had made during the research procedure in the lesson. This led us to the following conclusions: first, like the lesson drawings, the test drawings are appearancebased schemata visualisations; and second, there is a clear traceability between the lesson drawing and the test drawing of the same student. This means that most 
of the students in the experimental group "visually quoted" their lesson drawings, which implies an easy and effective visual recall. However, when comparing the lesson drawings and the test drawings, certain modifications are also noticeable (see Figures 1 and 7 by the same student): in comparison to the lesson drawings, the test drawings reflect a tendency towards simplification (simplification of composition, adding or deleting frames, abandoning signs and adding others, abandoning or adding details, etc.) and unification with the drawings of other students; in general, there is a tendency towards abandoning individual, divergent elements and adding convergent, common elements. This can be explained by adaptation to the group, as, in the second step of the research procedure during the lesson, the students were engaged in social learning when discussing the definition in pairs and viewing each other's drawings. For example, if we compare drawings by the same student (Figures 2 and 8), we can observe the following: the perspective changes from first-person narrative (which is highly divergent) to third-person narrative (which converges with the group); in the test drawing, the details become more elaborate, with each concept gaining its own visual sign, and the whole drawing is more of a word for word illustration of the definition; a new smiley character appears, which visually symbolises the emotional responses of artists. It is also instructive to notice that the same student makes a successful literal, word by word transcription of the definition in the second task in the test ("write the definition"; see below, "Code 3 " in Table 2).

Visualisations thereby prove to be a way to research and study the interaction between the process of individual learning and learning within the group as a learning community.

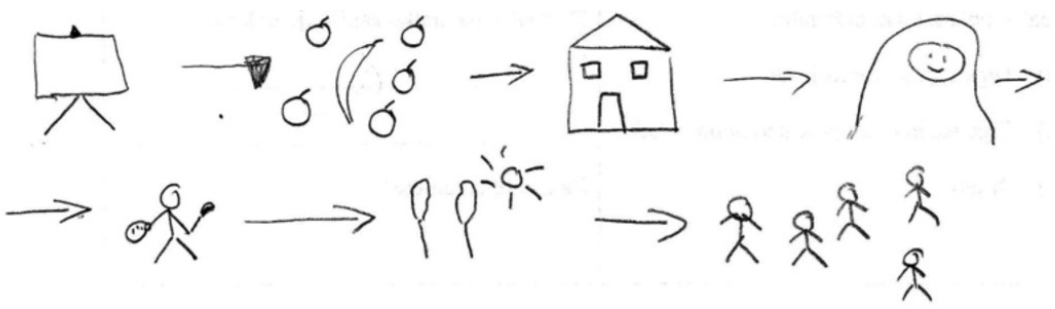

Figure 7

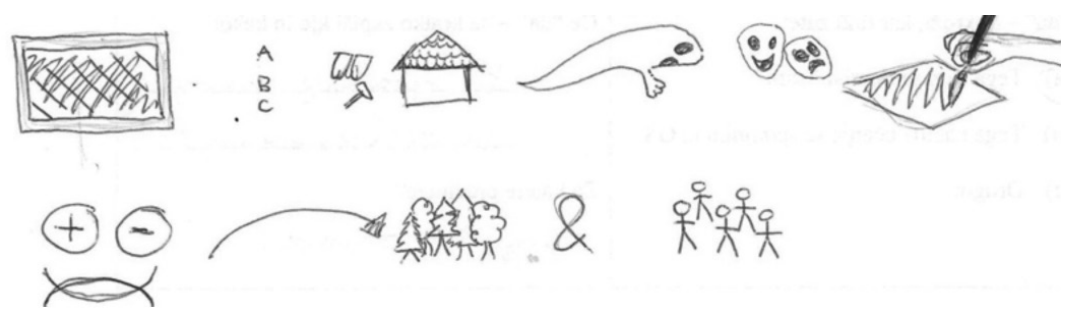

Figure 8 
Next, we analysed the correlations between the first task, "draw the definition", and the second task, "write the definition", between the control group and the experimental group. The findings are as follows (Table 1):

Nine students $(20 \%)$ in the control group did not solve either of the tasks, whereas there was only one such student $(2 \%)$ in the experimental group. Therefore, $92 \%$ of the students in the experimental group solved both tasks, compared to only $56 \%$ of the students in the control group.

Six students $(13 \%)$ in the control group only solved the second task, whereas there were no such students in the experimental group. This means that, in the experimental group, the visual experience complemented the verbal experience in every case, which confirms the assumption of the mutual reinforcing of multisensory experiences in memorising.

Five students $(11 \%)$ in the control group solved the first task but did not solve the second task, whereas there were three (6\%) such students in the experimental group. Two of these students in the control group made a correct and complex drawing (Figure 9 and 10), although they were not able to "write a definition" in the second task. In both groups together, there is a higher percentage $(8 \%)$ of students who solved the first task only ("draw the definition") than students (6\%) who solved the second task only ("write the definition"). This perhaps mirrors a characteristic of the contemporary generation of youngsters, who are more confident in expressing themselves in visual than in verbal media. Since taking the test was not obligatory in any way, the students could leave tasks that they found too difficult unsolved without any consequences; they therefore invested as much effort in the test as they wanted to. Thus, the fact that some students, when taking the test, were not able to express their knowledge verbally does not necessarily mean that they did not acquire the knowledge; on the contrary, it could indicate that they merely need another medium to express their knowledge. Based on the analysis of the drawings of both groups, it was concluded that even those students who have difficulties in forming meaningful written messages can visualise quite effortlessly. This indicates that contemporary students need alternative forms of expressing their knowledge in schools.

Table 1. Correlations between the first task "draw the definition" and the second task "write the definition" in the test

\begin{tabular}{llllll}
\hline Group & $\begin{array}{l}\text { Drawing and } \\
\text { writing }\end{array}$ & $\begin{array}{l}\text { No drawing - } \\
\text { no writing }\end{array}$ & $\begin{array}{l}\text { No drawing - } \\
\text { writing }\end{array}$ & $\begin{array}{l}\text { Drawing - } \\
\text { no writing }\end{array}$ & Together \\
\hline Control & $25(56 \%)$ & $9(20 \%)$ & $6(13 \%)$ & $5(11 \%)$ & $45(100 \%)$ \\
Experimental & $47(92 \%)$ & $1(2 \%)$ & $0(0 \%)$ & $3(6 \%)$ & $51(100 \%)$ \\
\hline Total & $72(75 \%)$ & $10(10 \%)$ & $6(6 \%)$ & $8(8 \%)$ & $96(100 \%)$ \\
\hline
\end{tabular}




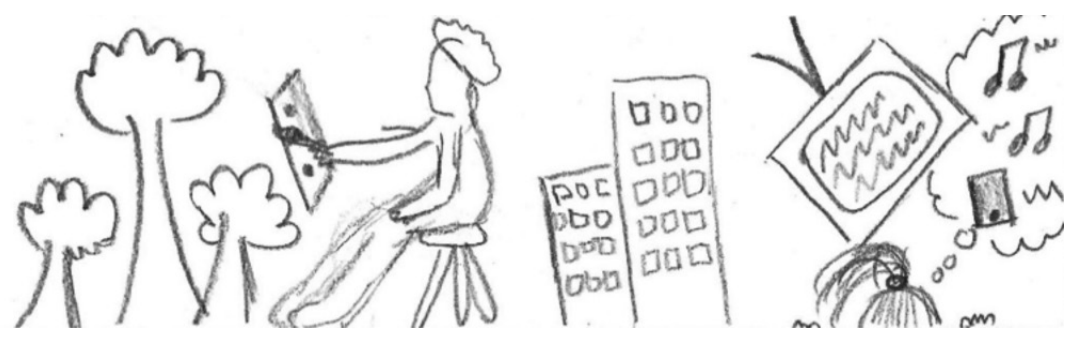

Figure 9

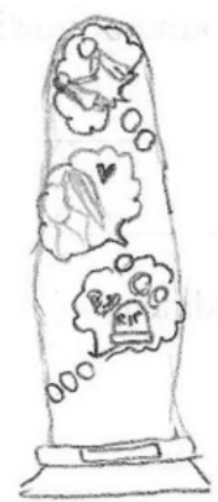

Figure 10

\section{Task 2: "Write the definition"}

The objective of the second task was to examine whether and to what extent the experimental group improved in their ability to memorise and understand the verbal definition in the long term in comparison to the control group. If a significant difference was found in this regard, it could be attributed to the impact of visualisation, as that was the only variable between the groups.

The students' answers were coded into six categories in relation to the degree of understanding and accuracy of the written definition (Table 2). In each example of the student's writing of the definition, we counted the number of concepts/terms that matched the concepts/terms in the original definition (we considered the concept/term to be correct even if it was used in a different declination or if the sequence of words was different from the original; however, we did not consider synonyms correct). The maximum possible number of concepts/terms is 11, which matches the number of concepts/terms in the original definition in Slovenian. 
Table 2. Categorisation and coding of the students' writings in the second task

\begin{tabular}{lll}
\hline \multirow{2}{*}{$\begin{array}{l}\text { Level of } \\
\text { memorisation }\end{array}$} & \multicolumn{2}{l}{ Categorisation and coding of writings } \\
\cline { 2 - 3 } High & Literal accuracy & Understanding \\
\hline & $\begin{array}{l}\text { Code } 3 \\
\text { Accurate record (tolerance of 1 error) }\end{array}$ & $\begin{array}{l}\text { Code } 4 \\
\text { Proper understanding expressed in the } \\
\text { student's own words (revealing inter- } \\
\text { nalised knowledge and its integration } \\
\text { into the student's cognitive system) }\end{array}$ \\
Medium & $\begin{array}{l}\text { Code 2 } \\
\text { occurate with some errors (tolerance }\end{array}$ & $\begin{array}{l}\text { Code } 5 \\
\text { partial understanding }\end{array}$ \\
Low & $\begin{array}{l}\text { Code } 1 \\
\text { Incomplete understanding or very inadequate record (more than 3 errors) }\end{array}$ \\
Zero & $\begin{array}{l}\text { Code } 0 \\
\text { No answer or only a few words that do not form a sentence }\end{array}$ \\
\hline
\end{tabular}

Some interesting and illustrative examples of the students' writings in the second task are given below according to the different codes:

- Code 0: "Art, Society... I don't remember anything else."

- $\quad$ Code 1: "He drew a free composition, geometrical shapes with different colour shades and contrasts."; "Painting is a way of life in nature and society - the artist is drawing something..."; "A work of art affects the artist's society and the environment in which he is."; "Art is associated with spirituality."

- $\quad$ Code 2: "A work of art is a materially existential and spiritual response of an artist to the situation in nature and society."; "A work of art is a way of expressing the artist's existence and spiritual responses to the situation in nature."

- $\quad$ Code 3: "A work of art is a material existence of the artist's spiritual responses to the situation in nature and society."

- $\quad$ Code 4: "A work of art comes to life when an artist transfers his thoughts, impressions from nature and the relations between nature and society into some material form."

- $\quad$ Code 5: "A work of art is the author's expression in a material and spiritual way. It impacts society and nature."

Based on these categories, the students' answers were grouped as shown in Table 3. It was found that, in the experimental group in comparison to the control group, there is a statistically significant higher number of literally accurate records (Code 3) and records showing understanding (Code 4), and a 
statistically significant lower number of tasks left unanswered (Code 0$):\left(\chi^{2}\right)=$ 10, $8(\mathrm{p}=0.01)$. Comparing the number of concepts/terms used in the writings, we discovered that the students in the experimental group used a statistically significant higher number of concepts/terms from the definition $(7 \pm 3)$ than students in the control group ( $4 \pm 4$, Mann-Whitney $\mathrm{U}$ test $\mathrm{p}<0.01$ ).

Table 3. Number of student writings by category for the second task.

\begin{tabular}{llcc}
\hline \multirow{2}{*}{$\begin{array}{l}\text { Level of } \\
\text { memorisation }\end{array}$} & Category & \multicolumn{2}{c}{ Number of student writings } \\
\cline { 3 - 4 } & & Experimental group & Control group \\
\hline High & Code 3 and Code 4 & 25 & 11 \\
Medium & Code 2 and Code 5 & 15 & 14 \\
Low & Code 1 & 7 & 6 \\
Zero & Code 0 & 4 & 14 \\
\hline
\end{tabular}

Task 3: "Pick the correct statement"

The results of the third task are presented in Tables 4 and 5. Table 4 gives an overview of the number of correct statements chosen by the students in each group, while the Table 5 provides an overview of the number of incorrect statements chosen by the students in each group.

Table 4. Overview of the number of correct statements per group

\begin{tabular}{lcc}
\hline \multirow{2}{*}{ Number of correct statements } & \multicolumn{2}{c}{ Number of students } \\
\cline { 2 - 3 } & Experimental group & Control group \\
\hline 0 & 0 & 3 \\
1 & 20 & 21 \\
2 & 31 & 21 \\
\hline Total & 51 & 45 \\
\hline
\end{tabular}

Table 5. Overview of the number of incorrect statements per group

\begin{tabular}{lcc}
\hline \multirow{2}{*}{ Number of incorrect statements } & \multicolumn{2}{c}{ Number of students } \\
\cline { 2 - 3 } & Experimental group & Control group \\
\hline 0 & 37 & 39 \\
1 & 14 & 3 \\
$\geq 2$ & 0 & 3 \\
\hline Total & 51 & 45 \\
\hline
\end{tabular}


Table 4 shows that the students in the experimental group chose more correct statements (all of the students in the experimental group marked at least one correct statement). A total of 31 of the 52 students in the experimental group (61\%) marked both correct statements, while the number of such students in the control group was only 21 out of 45 (47\%); however, an $\chi^{2}$ test shows no statistically significant differences. The number of incorrect statements per group (Table 5) reveals that the students in the experimental group chose statistically significantly fewer wrong statements than the students in the control group $\left(\chi^{2}=9.8, \mathrm{p}<0.01\right)$.

\section{Conclusion}

In our research, both of our hypotheses were confirmed: it was confirmed that the active visualisations that students use spontaneously are appearance-based schemata visualisations; it was also confirmed that the memorising of a verbal definition by students in the experimental group, where visualisation was added to verbal learning techniques, was better than in the control group, where students only used verbal learning techniques. Therefore, we can confirm that visualisation significantly contributes to memorising and understanding verbal definitions.

The type of visualisation investigated in our empirical research was appearance-based analogy; we therefore see two ways of further investigating the problem. Despite the fact that most of the students spontaneously acquired appearance-based schemata in their visualisations, we discovered that a higher level of formal awareness and ingenuity was present amongst individual students (e.g., Figure 11). Further research could therefore examine what type of visualisation students would acquire (and how it would impact memory and understanding) if they were more systematically encouraged to delve into the formal and aesthetic dimensions of visualisation. This also opens up the problem of the relationship between the artistic and the visual, a problem to which various degrees of importance are attributed by different authors. Authors who are not artists themselves (Barry, 1997; Plantinga, 1995; Williams, 2007) define artistic/visual literacy as one and the same, mainly placing importance on appearance-based visualisations. On the other hand, authors who are themselves artists (Butina, 1995; Muhovič, 1998; Selan, 2012) understand artistic literacy as formally more complex than visual literacy, thus differentiating between form-based and appearance-based visualisations. The question then arises as to how visualisations that are formally and aesthetically more complex (perhaps even artistic) influence memorisation and understanding in comparison to the spontaneous use of appearance-based schemata visualisations. 


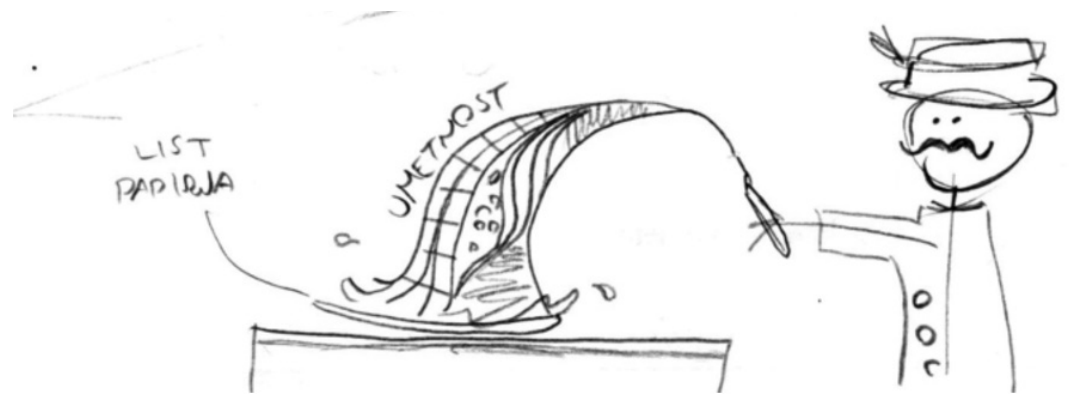

Figure 11

We can sum up as follows. Since visualisation obviously provides general cognitive benefits for students in memorising and understanding different school subjects, the education system should cultivate artistic/visual literacy in a similar way to verbal and mathematical literacy. In order to achieve this, teachers (not only art teachers, but all teachers) should themselves first master visual literacy and be trained in visualisation (just as they master verbal literacy). There are already some established practices of training teachers of different subject areas in visual literacy and the introduction of artistic practices into general educational use. ${ }^{5}$

\section{Acknowledgements}

We would like to sincerely thank Mojca Božič for her statistical analysis and advice on how to conduct the research. We would also like to thank Mihaela Gregorc for enabling the participation of the students in the research.

5 For instance, the programme of Purdue University (USA) for the professional development of teachers of English as a foreign language and for students of education is designed to strengthen the visual literacy of teachers, enabling them to use visualisation for the planning and implementation of their classroom practices (Britisch, 2009). In a similar way, the project Boston High School Renewal Initiative encourages teachers to actively introduce visual literacy into different classes. Also, at Lesley University (USA) the Institute for the Use of Graphic Expression in the School System - GRAFIC Center for Design and Education was established for promoting visual literacy amongst teachers (Myatt, 2008). 


\section{Sources and literature}

Arnheim, R. (1969). Visual Thinking. Berkeley: University of California Press.

Barry, A. M. (1997). Visual Intelligence, Perception, Image, and Manipulation in Visual

Communication. Albany: State University of New York Press.

Biesta, G. (2008). Good Education in an Age of Measurement: On the Need to Reconnect with the Question of Purpose in Education. Educational Assessment, Evaluation and Accountability, 21(1), 33-46.

Britisch, S. (2009). ESOL Educators and the Experience of Visual Literacy. TESOL Quarterly, 43(4), $710-721$.

Burmark, L. (2002). Visual Literacy: Learn to See, See to Learn. Alexandria: Association for Supervision and Curriculum Development.

Butina, M. (1995). Slikarsko mišljenje: od vizualnega k likovnemu [Painting Thinking: from Visual Thinking to Artistic Thinking]. Ljubljana: Cankarjeva založba.

De Bono, E. (1989). De Bono's Thinking Course. London: BBC Books.

Elkins, J. (2000). How to Use Your Eyes. New York, London: Routledge.

Frelih, Č. (2013). Likovna vzgoja: likovno opismenjevanje ali zgodovinjenje prihodnosti [Art Education: Artistic Literacy or Historicizing the Future]. Vzgoja in izobraževanje, 4(4-5), 48-49. Frelih, Č. (2014). K likovnim perspektivam za slepe [Towards the Artistic Perspectives for the Blind]. In K. Majerhold (Ed.), Zbornik za spodbujanje demokratičnega emancipiranega dialoga med ponudniki kulturnih dobrin in obiskovalci [Proceedings for Promoting Democratic Emancipated Dialogue between Providers of Cultural Goods and Visitors] (pp. 98-113). Ljubljana: Društvo ŠKUC, Galerija Škuc. Retrieved 12.09.2014 from www.so-delujem.com/uploads/page_files/269_aktivzbornik.pdf. Furlan, I., \& Kobola, A. (1970). Slika u nastavi i učenju [Picture in Teaching and Learning]. Zagreb: Zavod za unapredivanje osnovnog obrazovanja SR Hrvatske.

Jiang, X., \& Riesenhuber, M. (2015). Adding Words to the Brain's Visual Dictionary: Novel Word Learning Selectively Sharpens Orthographic Representations in the VWFA. The Journal of Neuroscience, 35(12), 4965-4972.

LeVan, A. (2009). Seeing is Believing: The Power of Visualisation. Retrieved 17.08.2015 from www. psychologytoday.com/blog/flourish/200912/seeing-is-believing-the-power-visualization.

Mendelson, A. L. (2004). For Whom is a Picture Worth a Thousand Words? Effects of the Visualizing Cognitive Stile and Attention on Processing of News Photos. Journal of visual literacy, 24(1), 85-105. Muhovič J. (1998). Vizualizacija, znanost in znanje [Visualisation, Science and Knowledge].

Anthropos, 3o(1/3), 42-81.

Myatt, L. (2008). Connecting the Dots: The Unexplored Promise of Visual Literacy in American Classrooms. The Phi Delta Kappan, 9o(3), 186-189.

Panić, V. (2005). Psihologija i umetnost [Psychology and Art]. Beograd: Zavod za udžbenike i nastavna sredstva.

Plantinga, C. (1995). Visual "Literacy": Image, Mind, and Reality by Paul Messaris. Film Qarterly, $48(4), 60-62$. 
Prevodnik, M. (2013). Za (s)likovno-vizualno, umetniško in za (o)pismen(je)nost za ustvarjalnost nam gre! [We are striving for pictorial-visual, artistic and creative literacy!]. Vzgoja in izobraževanje, 44(4-5), 17-25.

Rutar, D. (2013). Psihologija in jezik novih medijev [Psychology and the Language of New Media].

Vzgoja in izobraževanje, 44(4-5), 56-58.

Rutar Ilc, Z. (2013). Umetniška pismenost - za izbrance ali za vsakogar? [Artistic Literacy - only for the chosen ones or for anyone?]. Vzgoja in izobraževanje, 44(4-5), 4-5.

Selan, J. (2012). Biti vmes - umetnost kot praxis [Beiing In-between - Art as Praxis]. Phainomena, $21(80 / 81), 51-65$.

Sort, K. G., Harste, J. C., \& Burke, C. (1996). Creating Classrooms for Authors and Inquiries.

Portsmouth: Heinemann.

Šmajdek, A. (2013). Vizualizacija literature z likovnimi metodami [Visualisation of Literature by Artistic Methods]. In M. Orel (Ed.), Sodobni pristopi poučevanja prihajajočih generacij [Modern approaches to teaching coming generation], International Conference EDUvision 2013, Ljubljana, 28th \& 29th November 2013 (pp. 346-360). Polhov Gradec: Eduvision.

Tomšič Čerkez, B., Karim, S., Prevodnik, M., Selan, J., Šmajdek, A., \& Železnik, A. (2011). Likovna umetnost [Fine Arts]. In N. Bucik, N. Požar Matijašič, \& V. Pirc (Eds.), Kulturno-umetnostna vzgoja, Priročnik s primeri dobre prakse iz vrtcev, osnovnih in srednjih šol - dopolnjena spletna različica [Cultural and Art Education, A Manual with Examples of Good Practice from Kindergartens, Primary and Secondary Schools - an Updated Online Version] (pp. 217-213). Ljubljana: Ministrstvo za šolstvo in šport, Zavod RS za šolstvo.

Tomšič Čerkez, B. (2013). Raziskovanje sveta likovnovizualne podobe [Exploring the World of Visual Art Image]. Vzgoja in izobraževanje, 44(4-5), 30-33.

Trumbo, J. (1999). Visual Literacy and Science Communication. Science Communication, 20(4), 409-425.

Tulving, E. (1972). Episodic and Semantic Memory. In E. Tulving \& W. Donaldson

(Eds.), Organization of Memory, (pp. 381-403). New York: Academic Press.

Twissel, A. (2014). Visualisation in Applied Learning Contexts: A Review. Educational Tecxnology \& Society, $17(3), 180-191$.

Udir, V. (2013). Vloga slike v naravoslovju in pri fiziki [The Role of Images in Natural Sciences and Physics]. Vzgoja in izobraževanje, 44(4-5), 76-78.

Valery, P. (1995). Degas, ples, crtež [Degas, Dancing, Drawing]. Zagreb: Mladost.

Vogrinc, J., \& Devetak, I. (2007). Ugotavljanje učinkovitosti uporabe vizualizacijskih elementov pri pouku naravoslovja s pomočjo pedagoškega raziskovanja [Determining the Effectiveness of the Use of Visualisation Elements in Natural Sciences Education with the Help of Educational Research Methods]. In I. Devetak (Ed.), Elementi vizualizacije pri pouku naravoslovja [Elements of Visualisation in Natural Sciences Education] (pp. 197-213). Ljubljana: Pedagoška fakulteta Ljubljana. Williams, T. L. (2007). "Reading" the Painting: Exploring Visual Literacy in the Primary Grades. The Reading Teacher, 6o(7), 636-642. 


\section{Biographical note}

ANAMARIJA ŠMAJDEK is an artist (a sculptor) and an art teacher at High School Josip Jurčič, Ivančna Gorica, Slovenia. She is a doctoral student at University of Ljubljana, Faculty of Education, Slovenia.

JURIJ SELAN is an artist (a painter), an art theorist and an art teacher. $\mathrm{He}$ is an assistant professor of art theory and works at the Department of Art Education at University of Ljubljana, Faculty of Education, Slovenia. 